\title{
HOW IMPORTANT ARE THE IMPLANT INCLINATION AND THE INFRASTRUCTURE MATERIAL USED IN IMPLANT SUPPORTED FIXED PROSTHESES?
}

\begin{abstract}
Objectives: The aim of this study is to evaluate the stress, which is caused by the fixed prosthesis under oblique forces around dental implants and bone by using different infrastructure materials and different inclusions, by 3-dimensional (3D) finite element analysis (FEA) method.
\end{abstract}

Materials and Methods: 3D-FEA models of mandible, dental implants and prostheses were designed. The anterior and posterior implants were designed $10 \mathrm{~mm}$ in length and $4.3 \mathrm{~mm}$ in diameter. The anterior implant was placed parallel to each model. Posterior implant designed to make inclinations those mesial $17^{\circ}$, distal $17^{\circ}$, buccal $17^{\circ}$, lingual $17^{\circ}$. Implant supported fixed restorations were divided into 3 main groups according to the infrastructure materials. These materials were; chromium-cobalt, zirconia, polyetheretherketone (PEEK). In each model, a total of $500 \mathrm{~N}$ oblique force was applied from the buccal tubercle crests to the buccolingual direction at an angle of 30 degrees to the long axis of the tooth. Maximum principal (tensile) stress and minimum principal (compressive) stress values in the bone models were taken. In addition, von Mises stress values were obtained from implants and substructure materials.

Results: When the stress findings in the mandible during oblique loading were evaluated, it was found that the stresses on the cortical bone were higher than the stresses on the trabecular bone. It was observed that the highest stress values occurred in the implants.

Conclusions: It is thought that chromium-cobalt and zirconia-based ceramic bridge restorations are more positive in terms of stress distribution than PEEK-based ceramic bridge restorations.

Keywords: Finite element analysis, implant-supported dental prosthesis, polyetheretherketone, zirconia.
Afra Eda Karadayı Yüzükcü ${ }^{1}$

* Kaan Yerliyurt ${ }^{2}$

ORCID IDs of the authors:

A.E.K.Y. 0000-0002-2071-5092

K.Y. 0000-0002-9236-2732

${ }^{1}$ Prosthodontist, Istanbul, Turkey.

${ }^{2}$ Department of Prosthodontics, Faculty of Dentistry, Tokat Gaziosmanpasa University, Tokat, Turkey.

Accepted : 09.11.2021

How to Cite Karadayı Yüzükcü AE, Yerliyurt K. How Important are the Implant Inclination and the Infrastructure Material Used in Implant Supported Fixed Prostheses? Cumhuriyet Dent J 2021;24:4:395-402.

*Corresponding Author:

Department of Prosthodontics, Faculty of Dentistry, Tokat Gaziosmanpasa University, Tokat, Turkey.

Phone: + 903562124222 - (7426) $\quad$ Mobile Phone: + $905557240495 \quad$ Fax: + 903562124225

E-mail: kaanyerliyurt@hotmail.com 


\section{INTRODUCTION}

Dental implant applications have become a current treatment option in dental clinics due to the increase in success rates. ${ }^{1,2}$ Implant-supported dental prosthesis are divided into two classes as fixed or removable. The biggest advantage of implant-supported fixed dental prosthesis is that patients are psychologically satisfied and have a longer life span compared to implant-supported partial prostheses. Implant-supported fixed prostheses have increased function, stabilization and more satisfactory results compared to partial removable prostheses. ${ }^{3}$

In order to achieve functional and aesthetically satisfactory results with successful implant placement in the mandibular region, appropriate angulation and positioning are required. ${ }^{4}$ The direction of implant placement is closely related to the transmission of occlusal loads. The placement angle or inclination of the implant is very important in terms of biomechanics. ${ }^{5,6}$

In implant-supported fixed prosthesis, the infrastructure material plays an important role in stress transmission to implant and the bone around the implant. It has been reported that zirconium, which is used as a infrastructure thanks to its aesthetic properties, provides very good marginal compatibility and sufficient durability with the implant. In addition, since metals are not used as a substructure material, there are no disadvantages such as the emergence of toxic and allergic reactions caused by ion release..$^{7-9}$ PEEK; which is a high performance polymer, has been used as an alternative to metal alloys in many industries since the late 1970s. There are many areas of use in dentistry such as endocrones, infrastructures of fixed prostheses, implant materials and parts, and removable prosthetic skeleton. ${ }^{10-14}$ The mechanical properties of PEEK are similar to dentin and enamel, making this material more advantageous and positive than alloy and ceramic restorations. ${ }^{15}$ Chrome-cobalt alloys are resistant to abrasion and corrosion. They are biocompatible, high modulus of elasticity that do not stain easily. Their high elastic modulus allows them to be prepared thinner. ${ }^{16}$ Among the prosthetic restorations on implants, porcelains with metal substructure are still the most preferred materials today. Their biggest advantages are their durability, good bonding to porcelain, cheap and easy access. However, metal-based porcelains have many disadvantages. Corrosion and allergy are the main disadvantages. ${ }^{17}$

The aim of this study is to evaluate the stresses around dental implants and bone which is caused by the oblique forces on 3-member fixed prosthes which was made by different infrastructure materials [chrome-cobalt $(\mathrm{Cr}-\mathrm{Co})$, zirconia, polyetheretherketone (PEEK)] and different implant inclusions (mesial $17^{\circ}$, distal $17^{\circ}$, buccal $17^{\circ}$, lingual $17^{\circ}$ ) by using $3 \mathrm{D}$-FEA method.

\section{MATERIALS AND METHODS}

Ethical approval was granted by the University of Tokat Gaziosmanpaşa, Ethics Committee of the Clinical Research (Project no: 21-KAEK-266). 3D-FEA model of the edentulous mandible is designed. While modeling the mandibular bone, Division - A bone with a width of more than 5 $\mathrm{mm}$ in the bucco-lingual direction and a vertical bone dimension of $10 \mathrm{~mm}$ was chosen. The NobelActive (Nobel Biocare, Gothenburg, Sweden) implants were used in the models of the study. The anterior and posterior implants were 10 $\mathrm{mm}$ in length and $4.3 \mathrm{~mm}$ in diameter. Implants were placed in teeth 45-47 position. The posterior implant was placed in 4 different directions with $17^{\circ}$ inclination (mesial $17^{\circ}$, distal $17^{\circ}$, buccal $17^{\circ}$ and lingual $17^{\circ}$ ). Anterior implant was placed in parallel in each model (Figure 1).

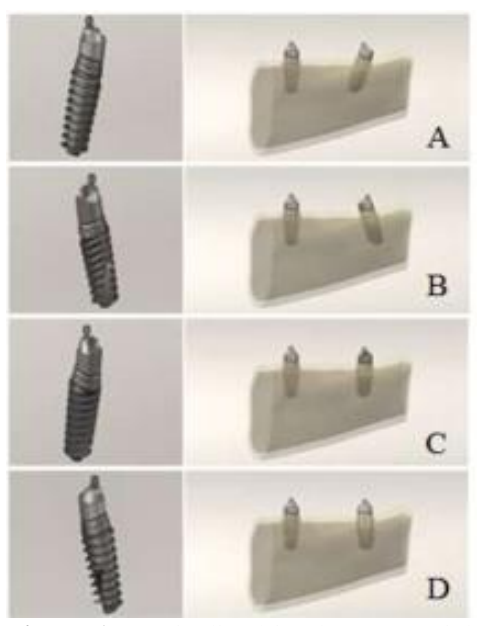

Figure 1. $17^{\circ}$ inclined implant to mesiale (A), $17^{\circ}$ inclined implant to distale (B), $17^{\circ}$ inclined implant to buccal (C), $17^{\circ}$ inclined implant to lingual (D).

The distance between implants were positioned to be $16 \mathrm{~mm}$. Cr-Co alloy, zirconia, PEEK material 
was used as infrastructure during the modeling of implant prostheses. Three different infrastructures were designed and the connector thickness was $2.5 \mathrm{~mm}$. (Figure 2).

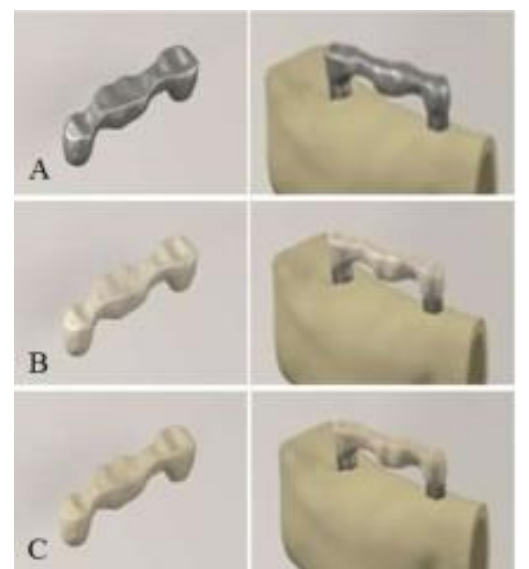

Figure 2. Cr-Co infrastructure (A), Zirconia infrastructure (B), PEEK infrastructure (C).

The implant and prosthesis parts supplied in the study were scanned in 3D optical scanner (Activity 880-Smart Optics, Sensortechnik GmbH, Bochum, Germany). The models obtained in.stl format were sent to Rhinoceros 4.0 (Robert McNeel \& Associates, Seattle, USA) 3D modeling software. With the Boolean method in Rhino software, harmonization was made between prosthesis upper and lower parts, implant screws and bone tissues and force transfer was achieved.

Thanks to this modeling technique, it has been tried to create the highest quality network structure with the highest possible node elements in order to facilitate the calculation. Young's modulus and Poisson's ratios of the materials and tissues that make up our study models are given in Table 1 .

Table 1. Young's modulus (elasticity modulus) and Poisson's ratios of the materials used in the study

\begin{tabular}{ccc}
\hline MATERIALS & Young's Modulus (MPa) & Poisson's Ratio \\
\hline Cortical bone & 13700 & 0.30 \\
Trabecular bone & 1370 & 0.30 \\
Titanium (implant and screws) & 110000 & 0.35 \\
Zirconia (infrastructure) & 205000 & 0.22 \\
Chrome-Cobalt (infrastructure) & 218000 & 0.33 \\
PEEK (infrastructure) & 4000 & 0.36 \\
Acrylic resin & 3000 & 0.35 \\
Feldspathic porcelain & 82800 & 0.35 \\
\hline
\end{tabular}

As a result, 4 subgroups were created according to the posterior implant angulation. Three different subgroups were created according to the infrastructure materials used in implant-supported bridge prosthes. In total, 12 finite element analyzes were performed. In each model, $500 \mathrm{~N}$ total oblique force was applied at an angle of 30 degrees from the buccal tubercle crests to the long axis of the tooth in the buccolingual direction. 100 $\mathrm{N}$ to the second premolar tooth, $200 \mathrm{~N}$ to the first molar and $200 \mathrm{~N}$ to the second molar (Figure 3).

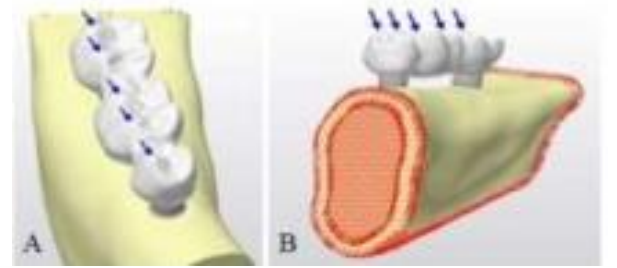

Figure 3. Oblique loads loaded from the buccal tubercle crests of restorations at an angle of $30^{\circ}$ (view from the mesial) (A), Oblique loads and red color in the meshed model the peripheral points are given zero degrees of freedom $(\mathbf{B})$.
The highest tensile stress and compressive stress values those occur in cortical and trabecular bone were analyzed. In addition, von Mises stress values were obtained from implants and infrastructures.

\section{RESULTS}

When the stress findings in the mandible during oblique loading were evaluated, it was found that the stresses on the cortical bone were higher than the stresses on the trabecular bone. It was seen that the highest stress values occurred in implants. When the stress values formed in the infrastructures were examined, it was seen that lower stress values occurred in the PEEK infrastructure models. When the stress values in posterior implants were examined, it was seen that higher stress values occurred in PEEK models.

Maximum principal (tensile) stress ( $\sigma \max )$ distributions in cortical bone during oblique loading 
are shown in Figure 4. In oblique loading, the maximum principle stres $\left(\sigma_{\max }\right)$ findings in cortical bone are shown in Figure 5.

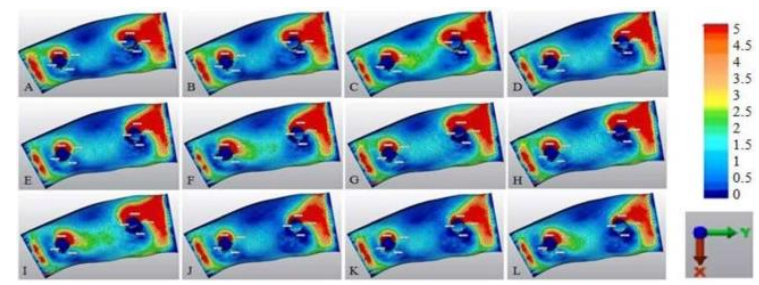

Figure 4. Maximum principal (tensile) stress $\left(\sigma_{\max }\right)$ distributions in cortical bone during oblique loading. Cr- Co / mesial $17^{\circ}$ (A), Zirconia/mesial $17^{\circ}$ (B), PEEK/mesial $17^{\circ}(\mathbf{C}), \mathrm{Cr}-\mathrm{Co} /$ distal $17^{\circ}$ (D), Zirconia/distal $17^{\circ}(\mathbf{E})$, PEEK/distal $17^{\circ}(\mathbf{F}), \mathrm{Cr}-\mathrm{Co} /$ buccal $17^{\circ}(\mathbf{G})$, Zirconia / buccal $17^{\circ}(\mathbf{H})$, PEEK / buccal $17^{\circ}(\mathbf{I})$, Cr- Co / palatinal $17^{\circ}(\mathbf{J})$, Zirconia / palatinal $17^{\circ}(\mathbf{K})$, PEEK / palatinal $17^{\circ}(\mathbf{L})$,

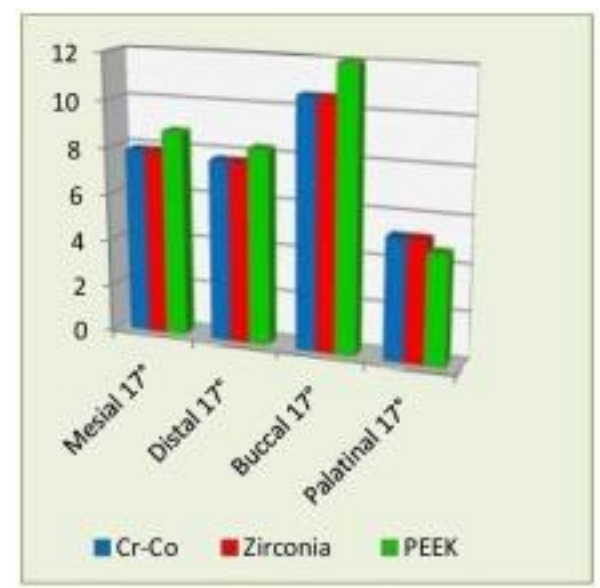

Figure 5. Maximum principal (tensile) stress $\left(\sigma_{\max }\right)$ values in cortical bone around the implant in oblique loading.
In this installation; the highest value in the selected node points in the cortical bone around the implant was $12 \mathrm{MPa}$ in the PEEK model with a $17^{\circ}$ inclination to the buccal, and the lowest value was 4.69 $\mathrm{MPa}$ in the PEEK model with a $17^{\circ}$ inclination to the palatinal.

The findings of the minimum principle (compressive) stresses occurring in the cortical bone in oblique loading are shown in Table 2 . In this installation; the highest value in the selected node points in the cortical bone around the implant was found to be $-30.74 \mathrm{MPa}$ in the mesiale $17^{\circ}$ inclined PEEK model and the lowest value was found as $-18.35 \mathrm{MPa}$ in the palatinal $17^{\circ}$ inclined Cr-Co model.

Table 2. Stress values in oblique loading (MPa)

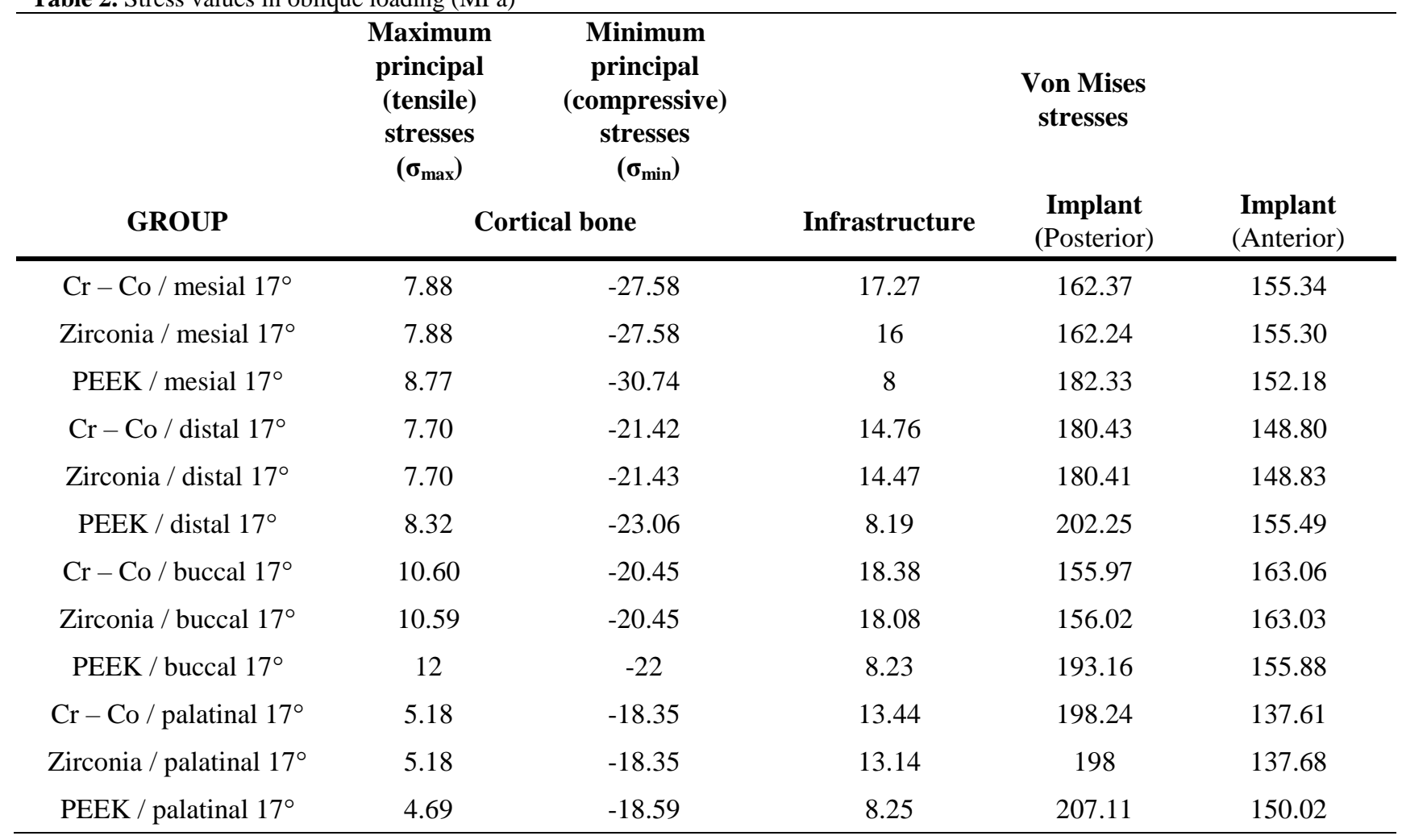


Von Mises stress distributions observed in infrastructures during oblique loading are shown in Figure 6. In oblique loading, the highest von Mises stress findings occurring in the infrastructure are shown in Figure 7. In this installation; the highest value was found to be 18.38 $\mathrm{MPa}$ in the group of $\mathrm{Cr}-\mathrm{Co}$ buccal-17 inclination and the lowest value was found in the group of PEEK mesial-17 ${ }^{\circ}$ inclination as $8 \mathrm{MPa}$.

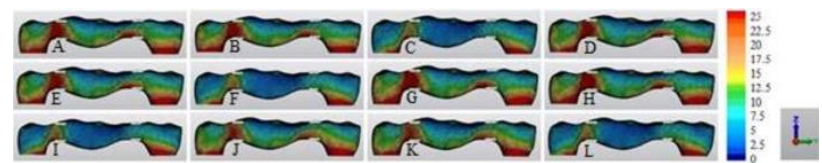

Figure 6. Von Mises stress distributions in infrastructures during oblique loading. $\mathrm{Cr}-\mathrm{Co} /$ mesial $17^{\circ}(\mathrm{A})$, Zirconia $/$ mesial $17^{\circ}(\mathrm{B})$, $\mathrm{PEEK} /$ mesial $17^{\circ}(\mathrm{C}), \mathrm{Cr}-\mathrm{Co} / \operatorname{distal} 17^{\circ}(\mathrm{D})$, Zirconia / distal $17^{\circ}$ (E), PEEK / distal $17^{\circ}(\mathrm{F}), \mathrm{Cr}-\mathrm{Co} /$ buccal $17^{\circ}(\mathrm{G})$, Zirconia / buccal $17^{\circ}(\mathrm{H})$, PEEK / buccal $17^{\circ}(\mathrm{I}), \mathrm{Cr}-\mathrm{Co} /$ palatinal $17^{\circ}(\mathrm{J})$, Zirconia / palatinal $17^{\circ}(\mathrm{K}), \mathrm{PEEK} /$ palatinal $17^{\circ}(\mathrm{L})$.

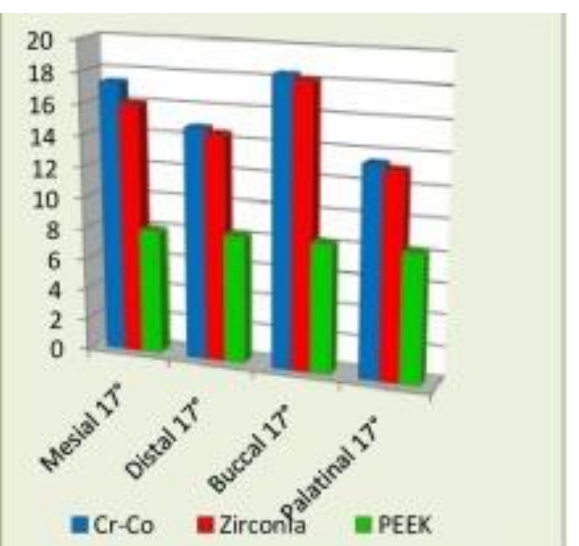

Figure 7. Von Mises stress values in infrastructures during oblique loading.

The von Mises stress distributions on implants are shown in Figure 8. The highest von Mises stress values in posterior implant during oblique loading are shown in Figure 9.

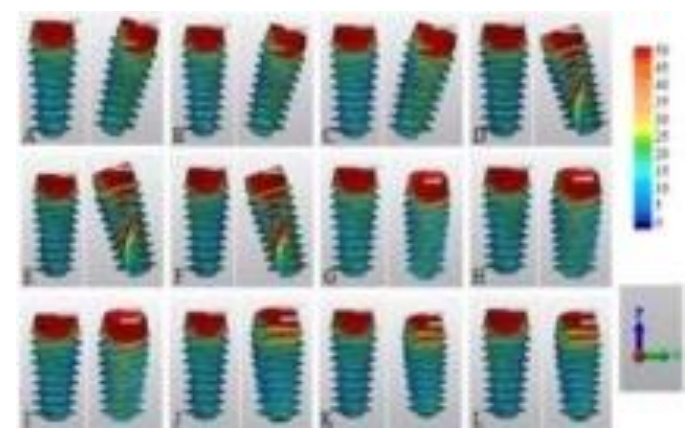

Figure 8. Von Mises stress distributions in anterior and posterior implants during oblique loading. $\mathrm{Cr}-\mathrm{Co} /$ mesial $17^{\circ}$ (A), Zirconia / mesial $17^{\circ}$ (B), PEEK / mesial $17^{\circ}$ (C), Cr- Co / distal $17^{\circ}$ (D), Zirconia / distal $17^{\circ}(\mathbf{E}), \mathrm{PEEK} / \operatorname{distal} 17^{\circ}(\mathbf{F}), \mathrm{Cr}-\mathrm{Co} /$ buccal $17^{\circ}$ (G), Zirconia / buccal $17^{\circ}(\mathbf{H})$, PEEK / buccal $17^{\circ}$ (I), Cr- Co / palatinal $17^{\circ}(\mathbf{J})$, Zirconia / palatinal $17^{\circ}(\mathbf{K})$, PEEK / palatinal $17^{\circ}$ (L).

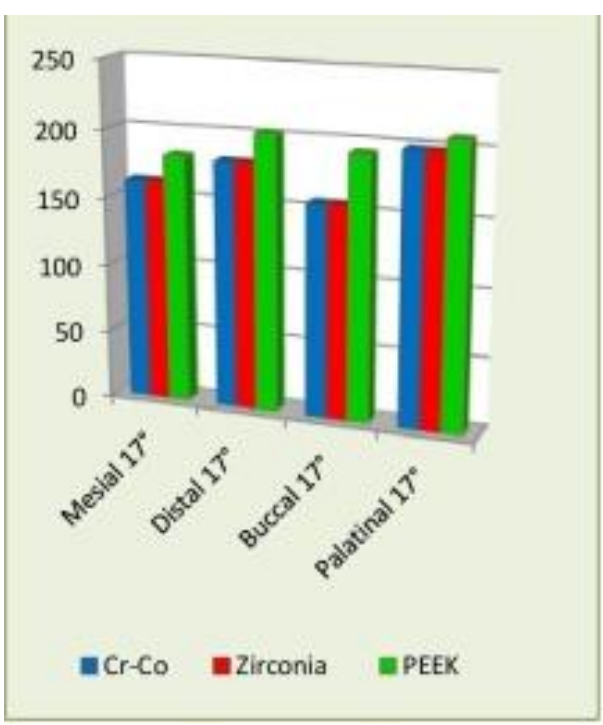

Figure 9. Von Mises stress values in posterior implant during oblique loading.

When the stress values were calculated, except for the groups with inclusion in the buccal direction, posterior implant values were found to be higher than the stress values in the anterior implant. In this installation; the highest value was found in the group of PEEK palatinal - $17^{\circ}$ inclination posterior implant (207.11 MPa) and the lowest value was found in the group of Cr-Co palatinal $17^{\circ}$ inclination anterior implant as $137.61 \mathrm{MPa}$ (Table 2).

\section{DISCUSSION}

It is impossible to determine the effect of biomechanical factors on the success of implantsupported prostheses by in vivo studies alone. In addition, it is very difficult to achieve standardization of in vitro and in vivo studies. Standardization can be achieved with finite element stress analysis and stress distributions can be determined digitally. ${ }^{18}$ At the same time, finite element analysis allows analysis to be carried out by changing only the determined factors and keeping all other factors constant. ${ }^{19}$ Due to these advantages, our study was carried out with finite element stress analysis.

Bone; although it is an inhomogeneous, anisotropic, viscoelastic structure, it is assumed that trabecular and cortical bone are homogeneous, isotropic and linear elastic in order to complete the analysis by simplifying the model. ${ }^{20}$ Therefore, in this study, trabecular and cortical bone was assumed to be homogeneous, isotropic and linear elastic, as in other studies. ${ }^{21-23}$ 
In our study we used the values for the Young's modulus (elastic modulus) and Poisson's ratios that which were used the mostly in the literature. $^{23-25}$

Sarot et al. ${ }^{10}$ said that oblique forces have a more destructive effect than vertical forces. Contrary to this, no study reporting was found. In our study, $200 \mathrm{~N}$ oblique force was applied to the molars and $100 \mathrm{~N}$ to the premolar tooth, in total $500 \mathrm{~N}$ oblique force. An angle of 30 degrees was preferred to use for oblique force.

Lee et $a l .{ }^{26}$ compared PEEK material with titanium and zirconia as a substructure material for implant-supported prostheses in a study they conducted with finite element analysis. As a result of this study, they found that the stress absorbing effects of the low elastic modulus substructure were limited in some areas and the stiffer substructure material showed a positive stress distribution in the components of the prosthesis.

In another study in the literature; cobaltchrome, titanium and zirconia prosthetic infrastructures were compared. Regardless of the treatment concept, harder materials such as cobalt-chromium and zirconia showed better biomechanical results; they created lower levels of stress on the bone, implant, abutment, abutment screw. $^{21}$

In a finite element analysis study; 2 different 3-member fixed prostheses were designed as porcelain on metal infrastructure and particulate composite coating on fiber reinforced composite infrastructure. After all; It was reported that while lower stress values were observed in the prosthesis parts in the composite content group, higher stress values were obtained in the implant abutment parts. ${ }^{27}$

In a study in which a finite element analysis was performed using titanium, zirconium and gold as an implant fixed prosthesis infrastructure; As a result of splinting implants with titanium or zirconia infrastructures, less stress values were observed around the implant and bone compared to gold. ${ }^{28}$
In our study, when the stresses on bone tissues and implants were examined, the highest values were observed in models using PEEK, and similar stresses were observed in models using zirconia and Cr-Co materials compared to PEEK, and it is seen that these results are compatible with the results of the above mentioned studies.

Zampelis et $a .^{29}$ in their study, they evaluated the effect of the connection of distal inclined implants with a fixed restoration on the stress distribution with two dimensional finite element analysis. In this study, $45^{\circ}$ distally inclined implants were compared with those placed vertically, and no significant increase was observed in bone stress in the neck region of the implant.

Satoh et al. ${ }^{5}$ prepared working models by inclining the implants placed in the mandibular bone to $10^{\circ}$ and $20^{\circ}$ mesial. The researchers used straight cylinder implants in their models, and the force applied in the study was applied parallel to the long axis of the tilted implant. The results showed that inclined placement of the implants did not adversely affect bone stress.

In our study, maximum principle stress value in the cortical bone was observed in the PEEK buccal 17 degrees inclined group, the lowest cortical bone tensile stress value was observed in the PEEK palatinal 17 degrees inclined group. The highest values observed in the buccal may be due to the application of oblique forces from the buccal direction.

\section{CONCLUSIONS}

PEEK material has the highest tensile and compressive stress values in cortical bone. When stresses occurring in implants are evaluated, the highest stresses occurred in models using PEEK material. Similar stresses were found at lower levels in models using $\mathrm{Cr}$-Co and zirconia material. When the von Mises stresses occurring in the substructures were evaluated, the highest stresses occurred in Cr-Co and zirconia models, and the lowest stresses occurred in PEEK models.

In the light of the results we have obtained; It is thought that $\mathrm{Cr}$-Co based ceramic bridge restorations and zirconia supported ceramic bridge 
restorations applied with the correct indication in fixed prostheses on implants will be more successful in terms of stress distribution compared to PEEK infrastructure restorations. It is thought that different inclination directions at the same angle have no important effect on stress values. Besides the advantages of the finite element analysis method, it also has some limitations. Therefore, the results obtained need to be supported by clinical studies.

\section{ACKNOWLEDGEMENTS}

This study was supported by the Scientific Research Projects Unit of Tokat Gaziosmanpaşa University with project number 2020/40.

This study, which was sent to the journal, was presented as a specialty thesis in the University of Tokat Gaziosmanpaşa, Faculty of Dentistry, Department of Prosthodontics.

\section{CONFLICT OF INTEREST}

The authors declare to have no conflict of interest.

\section{Implant Destekli Sabit Protezlerde İmplant Ĕgimi ve} Kullanılan Altyapı Malzemesi Ne Kadar Önemlidir? $\ddot{O} Z$

Amaç: Bu çalışmanın amacl, sabit protezlerin farklı altyapr malzemeleri ve farklı inklüzyonlar kullanarak dental implantlar ve kemik etrafindaki eğik kuvvetler altında neden olduğu stresi 3 boyutlu (3B) sonlu elemanlar analizi (SEA) yöntemi ile değerlendirmektir. Gereç ve Yöntemler: Mandibulada dental implant ve protezlerin 3B-SEA modelleri hazırlandl. Anterior ve posterior implantlar $10 \mathrm{~mm}$ uzunluğunda ve $4,3 \mathrm{~mm}$ çapında tasarlandi. Anterior implant her modele paralel olarak yerleştirildi. Posterior implant; mesiale $17^{\circ}$, distale $17^{\circ}$, bukkale $17^{\circ}$, linguale $17^{\circ}$ eğimli olacak şekillerde tasarland. Implant destekli sabit restorasyonlar alt yapl malzemelerine göre 3 ana gruba ayrlldi. Bu malzemeler; krom-kobalt, zirkonya, polietereterketon (PEEK). Her modelde bukkal tüberkül tepelerinden bukkolingual yöne dişin uzun eksenine 30 derecelik bir açıla toplam $500 \mathrm{~N}$ eğik kuvvet uyguland. Kemik modellerinde maksimum asal (çekme) gerilme ve minimum asal (basma) gerilme değerleri alındi. Ayrica implant ve alt yap malzemelerinden maksimum von Mises stres değerleri elde edildi. Bulgular: Oblik yükleme sirasinda mandibulada meydana gelen stres bulguları değgerlendirildiğinde, kortikal kemik üzerindeki streslerin trabeküler kemik üzerindeki streslerden daha yüksek olduğu bulundu. En yüksek stres değerlerinin implantlarda meydana geldiği görüldü. Sonuçlar: Krom-kobalt ve zirkonya esasll seramik köprü restorasyonlarının, stres dağllımı açısından PEEK esaslı seramik köprü restorasyonlarından daha olumlu oldukları düşünülmektedir. Anahtar kelimeler: Sonlu elemanlar analizi, implant destekli diş protezi, polietereterketon, zirkonya

\section{REFERENCES}

1. Pita MS, Anchieta RB, Ricardo Bara o VA, Garcia IR, Pedrazzi V, Assunca o WG. Prosthetic platforms in implant dentistry. J Craniofac Surg 2011;22(6):23272331.

2. Barbin T, Silva LDR, Daniele Valente Velôso DV, Borges GA, Camacho Presotto AG, Ricardo Barão VA, Groppo FC, Mesquita MF. Biomechanical behavior of CAD/CAM cobalt-chromium and zirconia full-arch fixed prostheses. J Adv Prosthodont 2020;12(6):329337.

3. Misch CE. Dental implant prosthetics. 2nd ed. St. Louis; Elsevier Mosby; 2014.

4. Payer M, Kirmeier R, Jakse N, Pertl C, Wegscheider W, Lorenzoni M. Surgical factors influencing mesiodistal implant angulation. Clin Oral Impl Res 2008;19(3):265-270.

5. Satoh T, Maeda Y, Komiyama Y. Biomechanical rationale for intentionally inclined implants in the posterior mandible using 3D finite element analysis. Int J Oral Maxillofac Implants 2005;20(4):533-539.

6. Watanabe F, Hata Y, Komatsu S, Ramos TC, Fukuda H. Finite element analysis of the influence of implant inclination, loading position, and load direction on stres distribution. Odontology 2003; 91(1):31-36.

7. Abduo J, Lyons K. Clinical considerations for increasing occlusal vertical dimension: a review. Aust Dent J 2012;57(1):2-10.

8. Tribst JPM, de Morais DC, Alonso AA, de Oliveira Dal Piva AM, Souto Borges AL. Comparative threedimensional finite element analysis of implantsupported fixed complete arch mandibular prostheses in two materials. J Indian Prosthodont Soc 2017;17(3):255-260.

9. Yildirim M, Edelhoff D, Hanisch O, Spiekermann

H. Ceramic abutments - a new era in achieving optimal 
esthetics in implant dentistry. Int $\mathbf{J}$ Periodontics Restorative Dent 2000;20(2):80-91.

10. Sarot JR, Contar CM, Cruz AC, de Souza Magini R. Evaluation of the stress distribution in cfr-PEEK dental implants by the three-dimensional finite element method. J Mater Sci Mater Med 2010;21(7):20792085.

11.Zoidis, $\mathrm{P}$. The all-on-4 modified polyetheretherketone treatment approach: a clinical report. J Prosthet Dent 2018;119(4):516-521.

12. Stawarczyk B, Eichberger M, Uhrenbacher J, Wimmer T, Edelhoff D, Schmidlin PR. Three-unit reinforced poly ether ether ketone composite FDPs: influence of fabrication method on load bearing capacity and failure types. J Dent Mater 2015;34(1):712.

13. Schmidlin PR, Stawarczyk B, Wieland M, Attin T, Hämmerle CHF, Fischer J. Effect of different surface pre-treatments and luting materials on shear bond strength to PEEK. Dent Mater 2010;26(6):553-559.

14. Schwitalla AD, Abou-Emara M, Zimmermann T, Spintig T, Beuer F, Lackmann J, Muller WD. The applicability of PEEK-based abutment screws. J Mech Behav Biomed Mater 2016;63:244-251.

15. Najeeb S, Zafar MS, Khurshid Z, Siddiqui F. Applications of polyetheretherketone (PEEK) in oral implantology and prosthodontics. J Prosthodont Res 2016;60(1):12-19.

16. Wataha JC, Messer RL. Casting alloys. Dent Clin North Am 2004;48(2):499-512.

17. Shadid RM, Sadaqah NR, Abu-Naba'a L, Al-Omari WM. Porcelain fracture of metal-ceramic toothsupported and implant-supported restorations: a review. Open J Stomatol 2013;3(8):411-418.

18. Sannino G, Pozzi A, Schiavetti R, Barlattani A. Stress distribution on a three-unit implant-supported zirconia framework. A 3D finite element analysis and fatigue test. Oral Implantol (Rome) 2012;5(1): 11-20.

19. De Rossi M, Santos CM, Miglioranca R, Regalo SC. All on four ${ }^{\circledR}$ fixed implant support rehabilitation: a masticatory function study. Clin Implant Dent Relat Res 2014;16(4):594-600.

20. Natali AN, Hart RT, Pavan PG, Knets I. Mechanics of bone tissue. In: Natali AN, editor. Dental biomechanics. London; Taylor and Francis Group; 2003. p.2-17.
21. Bhering, CL, Mesquita MF, Kemmoku DT, Noritomi PY, Consani RL, Barao VA. Comparison between all-on-four and all-on-six treatment concepts and framework material on stress distribution in atrophic maxilla: a prototyping guided 3D-FEA study. Mater Sci Eng C Mater Biol Appl 2016;69:715-725.

22. Cinel S, Celik E, Sagirkaya E, Sahin O. Experimental evaluation of stress distribution with narrow diameter implants: A finite element analysis. J Prosthet Dent 2018;119(3): 417-425.

23. Ozan O, Kurtulmus-Yilmaz S. Biomechanical comparison of different implant inclinations and cantilever lengths in all-on-4 treatment concept by three-dimensional finite element analysis. Int $\mathbf{J}$ Oral Maxillofac Implants 2018;33(1): 64-71.

24. Brizuela-Velasco A, Perez-Pevida E, JimenezGarrudo A, Gil-Mur FJ, Manero JM, Punset-Fuste M, Chávarri-Prado D, Diéguez-Pereira $\mathrm{M}$, Monticelli F. Mechanical characterisation and biomechanical and biological behaviours of Ti-Zr binary-alloy dental implants. Biomed Res Int 2017; ID 2785863.

25. Marcian P, Borak L, Valasek J, Kaiser J, Florian Z, Wolff J. Finite element analysis of dental implant loading on atrophic and non-atrophic cancellous and cortical mandibular bone-a feasibility study. J Biomech 2014;47(16):3830-3836.

26. 26. Lee KS, Shin SW, Lee SP, Kim JE, Kim JH, Lee JY. Comparative Evaluation of a four-implantsupported polyetherketoneketone framework prosthesis: a three-dimensional finite element analysis based on cone beam computed tomography and computer aided design. Int J Prosthodont 2017;30(6):581-585.

27. Erkmen E, Meric G, Kurt A, Tunc Y, Eser A. Biomechanical comparison of implant retained fixed partial dentures with fiber reinforced composite versus conventional metal frameworks: a 3D FEA study. J Mech Behav Biomed Mater 2011;4(1):107-116.

28. Hasan I, Bourauel C, Keilig L, Stark H, Luckerath $\mathrm{W}$. The effect of implant splinting on the load distribution in bone bed around implant-supported fixed prosthesis with different framework materials: a finite element study. Ann Anat 2015;199:43-51.

29. Zampelis A, Rangert B, Heijl L. Tilting of splinted implants for improved prosthodontic support: a twodimensional finite element analysis. J Prosthet Dent 2007;97(6): 35-43. 